\title{
3 Research Souare

\section{Investigation of Malaria Vectors (Diptera: Culicidae) in Agricultural Settlements in the Amazon Region of Brazil}

\section{Alice Oliveira Andrade}

Fiocruz Rondonia

Najara Akira Costa dos Santos

Universidade Federal de Rondonia

Raphael Brum Castro

Fiocruz Rondonia

Isabelle Sousa de Araujo

Fiocruz Rondonia

Alessandra da Silva Bastos

Universidade Federal de Rondonia

Felipe Neves Magi

Centro Universitário Aparício Carvalho

Moreno Magalhães de Souza Rodrigues

Fiocruz Rondonia

Dhélio Batista Pereira

Centro de Pesquisa em Medicina Tropical

Jansen Fernandes Medeiros

Fiocruz Rondonia

Maisa da Silva Araujo ( $\nabla$ maisaraujo@gmail.com )

Fiocruz Rondonia https://orcid.org/0000-0003-3607-0433

\section{Research}

Keywords: Nyssorhynchus darlingi, Natural infection, Settlements, Brazilian Amazon

Posted Date: March 2nd, 2021

DOl: https://doi.org/10.21203/rs.3.rs-252807/v1

License: (a) (i) This work is licensed under a Creative Commons Attribution 4.0 International License. Read Full License 


\section{Abstract}

Background: Environmental changes resulting from the urbanization process represent a challenge for malaria control. The majority of malaria cases in South America occur in rural areas, areas of recent occupation, mining and indigenous areas of the Amazon region. Although these areas have a significant impact on malaria cases, few entomological studies have been carried out in areas of recent occupation. This study aimed to describe the density, natural infection rate and hematophagic behavior of anopheline species in two settlements in the state of Rondonia, Brazil in order to understand how malaria transmission occurs in areas that have been settled at different times.

Methods: An area of recent occupation, denominated Acampamento Fortaleza (AF), and an old settlement, denominated Projeto de Assentamento Florestal Jequitibá (PAFJ), were studied. Peridomicile collections of anopheles were carried out using the Protected Human Attraction Technique (PHAT). The risk and potential for malaria transmission were assessed using the human biting rate (HBR), sporozoite rate (SR) and the entomological inoculation rate (EIR).

Results: The results confirmed that Nyssorhynchus darlingi, the main vector responsible for the transmission of malaria in the state of Rondônia, is the predominant species in the two studied locations. Although settlement of the two study sites has occurred at different times, the species richness found was low, showing that the environmental changes caused by anthropological actions probably favor the adaptation of the $\mathrm{Ny}$. darlingi species. Of the 615 anopheline mosquitoes assessed, $7(1.1 \%)$ were positive for Plasmodium infections. The EIR revealed that $N y$. darlingi contributes to the transmission of malaria in both locations, since it was responsible for 0.41 infectious bites in humans at night in PAFJ and 0.16 in AF. In the two study sites, the biting occurred more frequently at dusk.

Conclusions: $\mathrm{Ny}$. darlingi is the principal vector found in the studied locations. Its prevalence occurs in areas of recent colonization but, even when present in a low density, this species could maintain transmission of malaria in an older settlement. The entomological information obtained in this study is important and may aid the selection of vector control actions in these locations that are considered as having a high risk of malaria transmission.

\section{Background}

Despite the global efforts to reduce malaria, in the Americas, the incidence of malaria has been increasing since 2015, mainly due to the increases in cases in the areas of Amazon Rainforest of Venezuela, Colombia and Brazil [1]. In 2018, Brazil accounted for $23 \%$ of malaria cases in the Americas, which were mostly caused by Plasmodium vivax (79.5\%) and Plasmodium falciparum (20.5\%) [2]. The majority of these cases occur in rural areas of the Brazilian Amazon, such as riverine communities, indigenous areas, mines and rural settlements $[3,4]$.

The indigenous areas, mines and rural settlements are described by the Ministry of Health of Brazil as special areas for the control of malaria. This classification is due to the difficulty of access to these areas, but also by the precariousness nature of the housing, the alterations in human population movement in 
which families settle and leave, existence of illegal activities, differences in malaria control strategies and even cultural habits [3]. These special areas in the Brazilian Amazon increase the percentage of epidemics in different states and municipalities, since they are composed of non-immune people, who live in precarious housing and working conditions. In addition, some of these areas suffer from poor access to the health system, and lack of diagnosis further aggravates the problem in these locations $[3,5]$.

In 2019, $25 \%$ of malaria cases in the Brazilian Amazon were concentrated indigenous areas, followed by rural settlements (6\%) and mining areas (5\%). Fluctuations in the number of malaria cases in these areas are common due several factors, but mainly due the difficult of maintaining uninterrupted diagnosis and treatment. Up until 2009, the majority of malaria cases from special areas in the Amazon were registered in rural settlements, which was followed by a decrease and then an increase again in 2015 [6]. Historically, rural settlement projects in the Brazilian Amazon, created by the National Institute for Colonization and Agrarian Reform (INCRA), were one of the major determinants of malaria epidemics in Brazil [7]. Currently, the Brazilian Amazon has 3,120 registered rural settlements, which are mainly concentrated in the states of Maranhão, Mato Grosso, Pará, Tocantins, Rondonia and Acre [8].

The assessment of the emergence of malaria in rural settlements is known as "frontier" malaria, and considers, among other factors, the "settlement time" and "malaria incidence". The first years of occupation are marked by a rapid increase in malaria caused by ongoing anthropogenic changes in the environment, and several years after the initial settlements, a relative stability in malaria transmission occurs, with lower malaria rates resulting from the reduction in changes to the environment $[9,10]$. Moreover, in the first years of the settlements, vector density is high due transformations of the environment that provide a greater number of larva habitats $[9,11,12]$.

In several regions of the Brazilian Amazon, the main vector of malaria is the species Nyssorhynchus darlingi, formerly known as Anopheles darlingi [13]. This species is recognized as being the most efficient vector of malaria due to its highly anthropophilic behavior, susceptibility to human Plasmodium malaria parasites, large geographic distribution, and rapid adaptation to environmental changes [14-19]. Moreover, this vector has been found in high density levels and high contact levels with humans in the "frontier" malaria [20]. However, other anopheline species can be involved in malaria transmission as secondary or occasional malaria vectors at local and regional levels [21]. Although, these anophelines are as not well adapted as $\mathrm{Ny}$. darlingi in anthropogenic conditions [22], some species can emerge as the primary vectors in specific scenarios $[23,24]$.

In general, although there is a great discussion about the "frontier" malaria hypothesis in the Brazilian Amazon, investigations regarding the patterns of the structure of Anopheles populations in human settlements are few and anopheline diversity continues to be underestimated and with several species thought to be unknown in "frontier" malaria [25].

The population dynamics of the anophelines, hematophagic behavior (anthropophilic level, endophagic versus exophagic and biting activity) and natural anopheline infection rate are important in order to define efficient and sustainable strategies for vector malaria control [26, 27]. According to Santos et al. [28], the vector control for malaria can be inefficient if used it is not used in accordance with the hematophagic 
activity of mosquitoes. Moreover, other entomological metrics can be estimating the risk and potential for malaria transmission by mosquitoes in endemic areas, such as human biting rate (HBR), sporozoite rate (SR) and entomological inoculation rate (EIR) [29].

The state of Rondonia is situated in the Amazon Basin. In 2018, 7,685 cases of malaria were reported, with $3,600(46.8 \%)$ occurring in rural areas and $1,727(22.5 \%)$ in rural settlements [6]. The study site of this paper, the municipality of Candeias do Jamari, represents a risk area (annual parasite index - API > 50) [6] and entomological investigations in rural settlements are rare. Thus, the aim of our study was to describe anopheline species composition, and the HBR, SR and EIR of anopheline mosquitoes present in the peridomicile of two agricultural settlement areas in the municipality of Candeias do Jamari, Rondonia.

\section{Methods}

\section{Study area}

This study was performed in two rural locations in the municipality of Candeias do Jamari. Candeias do Jamari is located in the northwest of the state of Rondonia, Brazil, and is approximately $20 \mathrm{~km}$ from the state capital Porto Velho (Fig. 1). The climate is made up of a rainy season from November to Abril, and a dry season from May to October.

The municipality has a history of urbanization similar to other regions of the Brazilian Amazon, starting with implementation of settlement projects by the INCRA. The main economic activity is related to agriculture and livestock, resulting in an increase in fragmentation of the forest and a reduction of native vegetation.

The Acampamento Fortaleza (AF) ( $\left.8^{\circ} 39^{\prime} 41.0^{\prime \prime} \mathrm{S} 63^{\circ} 01^{\prime} 58.8^{\prime \prime} \mathrm{W}\right)$ is situated at the end of a trail located near highway marker 21 on state highway BR364 in the municipality of Candeias do Jamari (Fig. 1). This settlement is considered recent, with less than five years of occupation at the time that this research commenced. As the AF settlement has still not been registered by INCRA, this occupation is classified as a camp. Human dwellings are precarious and close to forest fragments (approximately $50 \mathrm{~m}$ ) and structures do not adequately protect residents from contact with vectors. The material for the construction of the houses is obtained from the forest and the clearing of the area for housing is done by burning. There is no electricity supply, and the water is obtained from creeks. The local population's livelihood comes from small plantations of banana, corn, beans and manioc, the rearing of small animals (pigs, chickens and ducks) and the extraction of wood from the forest.

The second location, Projeto de Assentamento Florestal Jequitibá (PAFJ) ( $8^{\circ} 41^{\prime} 00.5^{\prime \prime} \mathrm{S} 63^{\circ} 11^{\prime} 08.8^{\prime \prime} \mathrm{W}$ ) (Fig. 1) is a settlement that was established more than ten years ago in the municipality of Candeias do Jamari by INCRA under Decree No. 1,141/03 [30]. It is an anthropized environment and has little basic infrastructure (electricity and an access road). In general, human dwellings are made of wood or bricks and built about $1 \mathrm{~km}$ from the edge of the forest. The settlement is a reference point for farmers and other members of the local population, as well as a community meeting place for political and cultural activities. Local residents primarily depend on livestock farming (pigs and chickens), local commerce and sale of milk and homemade cheese. 
These locations were chosen according to the following criteria: i) malaria cases; ii) presence of the mosquitoes; iii) vegetation cover; iv) presence of breeding sites for anophelines; v) human presence and vi) access to locations. The locations are about $27 \mathrm{~km}$ apart from each other (Fig. 2).

\section{Malaria data}

The number of cases reported for the months of sample collection and the API for 2018 and 2019 in each location studied were obtained from Sistema de Informação de Vigilância Epidemiológica (SIVEP) Malaria database [31].

\section{Entomological collections}

Anopheline collections were performed 16 times at two dwellings in each location (Fig. 2). Eight of them were performed at the beginning of the rainy season (in October and November, 2018) and eight at the beginning of the dry season (in May and June, 2019). Protected Human Attraction Technique (PHAT) were performed outside the dwellings from 6 pm to 6 am (12 hours of collection).

Each capturer worked for six hours and then rested. Collection sites in human settlements were located outdoors, no more than $7 \mathrm{~m}$ from selected house (Fig. 2). Mosquitoes were placed in plastic containers that were labelled with the date, time and sample location. Climatic conditions, such as temperature and relative humidity, were recorded for each sampling interval of one hour using thermohygrometer (Incoterm). Data regarding the habits of the human population were registered. At the end of sample collections, the specimens were transported alive inside tightly closed isothermal boxes to the Entomology Laboratory at Fiocruz - Rondônia, Porto Velho, Brazil.

The following morning, the identification of the anophelines were performed using Consoli and Lourenço-deOliveira keys [32]. After identifications, up to 10 mosquitoes from same species collected at the same time and location were stored in $1.5 \mathrm{~mL}$ tubes with isopropanol. The tubes were kept at room temperature until Plasmodium spp detection using PCR were performed.

\section{Natural infection of mosquitoes by Plasmodium spp.}

Before the molecular analysis, heads and initial region of the thoraces of the anophelines were bisected from the abdomens [33] and transferred individually to new tubes. This procedure allows for the detection of sporozoite from the salivary gland. DNA was immediately extracted from the heads and initial region of the thoraces according to the Laporta et al. [23] protocol, with some adaptations. The extracted DNA was quantified using an UV-Vis spectrophotometer (Nanodrop 2000, Thermo Scientific ${ }^{\circledR}$, MA, USA) and its purity was also checked.

In order to determine malaria sporozoite infection rate, DNA from heads and initial region of the thoraces was used as a template for Plasmodium sporozoite DNA detection using nested PCR. The primer sequences and nested PCR reaction used in this study are described in Win et al. [34]. Amplification was done in a final volume of $15 \mu \mathrm{L}$, containing $1 \mu \mathrm{L}$ of genomic DNA $(<0.1 \mu \mathrm{g}), 0.25 \mu \mathrm{M}$ of each primer P1UP and P2, $0.2 \mathrm{mM}$ of each dNTPs (Invitrogen $\circledast$, Waltham, MA, USA), and 1 X 5 HotMaster primer buffer 0.1 unit of Taq DNA 
polymerase (5PRIME HotMaster Taq DNA Polymerase). PCR was performed in a thermocycler (Veriti®; Applied Biosystems, Foster City, USA) under the following conditions: $94^{\circ} \mathrm{C}$ for 2 minutes for initial denaturing, followed by 30 cycles at $94^{\circ} \mathrm{C}$ for 30 seconds, at $60^{\circ} \mathrm{C}$ for 30 seconds for amplification, and then at $68^{\circ} \mathrm{C}$ for 20 seconds for extension. The temperature was then reduced to $14^{\circ} \mathrm{C}$ until the samples were taken. An aliquot of $0.5 \mu \mathrm{L}$ of the first reaction was subjected to nested amplification for $P$. vivax (primers $\mathrm{P} 1$ and $\mathrm{V} 1$ ) and $P$. falciparum (primers $\mathrm{P} 1$ and $\mathrm{F} 1$ ) and mix reaction and cycling parameters following the first reaction, however with 15 cycles.

The amplified products $(5 \mu \mathrm{L})$ were subjected to GelRed staining followed by electrophoresis on agarose $1.5 \% \mathrm{gel}$ and the species-specific fragment sizes were $100 \mathrm{bp}$ for $P$. vivax and $P$. falciparum, which were visualized using a digital camera system (ImageQuant® TM LAS 4000, GE healthcare, Papua New Guinea).

\section{Data analysis}

The malaria transmission potential of mosquitoes was determined by estimating the human biting rates (HBR) and entomological inoculation rates (EIR) for each location. The HBR was scored as the average hourly number of mosquitoes captured per person per hour. The EIR was calculated by multiplying the HBR and the estimated sporozoite rates (SR). The SR is the proportion of mosquitoes positive for Plasmodium spp., which was detected by PCR.

\section{Results}

\section{Mosquitoes collections and human activity}

A total of 615 anophelines were collected in the outdoor area of the two locations. Nyssorhynchus darlingi was the most abundant species, representing $99.68 \%$ of the total number of anophelines collected. Only two other anophelines species were also collected; Nyssorhynchus triannulatus (0.16\%) and Anopheles peryassui $(0.16 \%)$ (Table 1$)$.

Table 1

Number of anophelines collected of Projeto de Assentamento Florestal Jequitibá (PAFJ) and Acampamento Fortaleza (AF).

\begin{tabular}{|lllllll|}
\hline SPECIES & \multicolumn{3}{l}{ LOCATIONS } & \multicolumn{3}{l|}{ TOTAL } \\
\cline { 2 - 9 } & PAFJ & AF & \multicolumn{3}{c|}{$\mathbf{N} \%$} & \\
& $\mathbf{N} \%$ & & $\mathbf{N} \%$ & & & \\
\hline Ny. darlingi (Root, 1926) & 68 & 100 & 545 & 99.64 & 613 & 99.68 \\
\hline Ny. triannulatus (Neiva and Pinto, 1922) & 0 & 0 & 1 & 0.18 & 1 & 0.16 \\
\hline An. peryassui (Dyar and Knab, 1908) & 0 & 0 & 1 & 0.18 & 1 & 0.16 \\
\hline Total & $\mathbf{6 8}$ & $\mathbf{1 0 0}$ & $\mathbf{5 4 7}$ & $\mathbf{1 0 0}$ & $\mathbf{6 1 5}$ & $\mathbf{1 0 0}$ \\
\hline
\end{tabular}

Patterns of biting activity of $\mathrm{Ny}$. darlingi by location and temperature/humidity are shown in Fig. 3. Overall, a higher concentration of mosquitoes was collected at the first part of the night (6 pm to $11 \mathrm{pm})$ at the two 
locations. After that, the number of mosquitoes captured gradually decreased.

Despite a low density of mosquitoes in the PAFJ, mosquitoes were captured in all hourly collections and showed a trimodal pattern, with biting peaks at $6 \mathrm{pm}, 8 \mathrm{pm}$ and $10 \mathrm{pm}$ (Fig. 3a). Human activity was observed during the whole night at this location, due to bars being open, but the majority of activities were concentrated at the beginning of the night since the population has a habit of taking a shower after $6 \mathrm{pm}$, meeting up and then having their meals outside the house.

On the other hand, the hourly biting activity at the AF was higher, though only less than twenty mosquitoes were captured after $2 \mathrm{am}$ (Fig. 3b). The highest biting peak at the AF was registered at $7 \mathrm{pm}$. Human exposure to the vector at this location is higher than at the PAFJ, mainly because of type of dwellings found there and types of human activity, such as hunting and fishing.

As a general observation, the families from AF have a habit of cooling off in the stream at dusk, women wash their clothes, dishes and other utensils and children enjoy playing there.

During the 12 hours of sample collection, the temperature did not present much variation, though there was fall in temperature after 7 pm (Fig. 3a-b). However, the humidity showed a gradual increase (Fig. 3) in both locations. However, the behavioral pattern of mosquitoes does not follow the pattern of temperature and humidity of both locations.

\section{Malaria epidemiological data}

During the months of collection, 16 malaria cases were reported in PAFJ. The API was almost the same during the 2018 and 2019 (API = 1,377.0 in 2018 and API = 1,344.2 in 2019). While, in the AF, 132 malaria cases were reported during the same period of mosquito collection in PAFJ and, in 2018, the API at this location was 1,048.6 and in 2019 the API was lower (API = 524.3).

\section{Human-biting rates (HBRs)}

The mean HBRs of all captures showed differences between the two locations. In the PAFJ, the HBR was 0.71 (SD \pm 0.67 ), while in the AF the HBR was higher, and 5.70 bites per person per hour registered (SD \pm 4.32). The higher HBR registered in the AF means that an individual who lives or visits the AF during the anophelines activity period is exposed almost five times more to mosquito bites than an individual who lives or visits the PAFJ.

\section{Natural infection of mosquitoes and risk of malaria transmission}

In order to assess the natural infection rates of anophelines with Plasmodium spp. in both locations, all the collected mosquitoes were individually analyzed using nested PCR. The Plasmodium sporozoite rates were $1.14 \%$ (7/615), being $0.81 \%$ (5/615) for $P$. vivax and $0.16 \%$ (1/615) for $P$. falciparum and $0.16 \%(1 / 615)$ for mixed infections (P. vivax+ P. falciparum).

The greatest number of infected mosquitoes was from the PAFJ, with an SR of 7.35\% (5/68), while only two mosquitoes were infected in the AF, which registered an SR of 0.37 (2/547). Both locations registered 
infections for $P$. vivax and $P$. falciparum; and the only mixed infection was registered in the PAFJ.

All infected mosquitoes belonged to the $\mathrm{Ny}$. darlingi mosquito species. Mosquitoes from the PAFJ that tested positive were collected at $7 \mathrm{pm}, 8 \mathrm{pm}, 10 \mathrm{pm}$ and 4 am, and mosquitoes that tested positive were collected from the AF at $10 \mathrm{pm}$ and $12 \mathrm{am}$.

To estimate the risk of contracting malaria during the study, the EIRs were calculated for each location. The number of infective bites a person might receive at the PAFJ during our study was 0.05 , while in the AF the number was lower $(E I R=0.02)$.

\section{Discussion}

Human activity without adequate planning and infrastructure in forest areas of the Brazilian Amazon can promote greater contact between man and vector and, consequently, intensify malaria transmission in different locations $[12,35]$. Furthermore, alterations in the land use could completely change the richness and composition of anopheline species, and thus change the dynamics of local malaria infections [36, 37]. The malaria control and prevention strategies currently developed by the Ministry of Health are not effective in areas in the Brazilian Amazon, such as rural settlements, that suffer increasing urbanization since entomological and epidemiological knowledge regarding these locations is limited.

In the current study, Ny. darlingi was the dominant species in settlement areas in the municipality of Candeias do Jamari, Rondonia, Brazil. This observation is accordance with the findings of other studies carried out in rural settlements in the Brazilian Amazon $[12,15,38]$. This mosquito species is abundant and contact rate with humans is high in studies of the first stage of frontier malaria [20]. Furthermore, $\mathrm{Ny}$. darlingi is a species that is well-adapted to anthropogenic changes in the forest environment when compared to other anopheline species $[17,20]$.

The more recent settlement in the present study (AF) showed the highest density of $\mathrm{Ny}$. darlingi and this was where other anopheline species were collected. Studies in rural settlements in Acre have reported a higher density of $\mathrm{Ny}$. darlingi in sample collections near a recent settlement, which suggests that a higher level of colonization decreases the vector presence [12]. If we consider the "frontier" malaria concept, our data regarding anopheline density confirm what occurs in the early stages of frontier settlement. The first phase of "frontier" malaria involves changes in the natural forest landscape, which alter the abiotic characteristics and ecology of larval habitats, and this leads to an increase in the abundance of the local vector [9].

The two other species of mosquitoes collected at the AF ( $\mathrm{Ny}$. triannulatus and An. peryassui) have already been described as vectors that inhabit the forest edge and stay away from domestic environments, but may be associated with human activity such as deforestation in the Amazon regions [39]. The houses in the AF settlement are closer to the forest, and deforestation is common because of the human colonization process in the area.

Nyssorhynchus darlingi was the only species of mosquitoes that was collected at the PAFJ and presented low density. This settlement has existed for more than ten years, the houses are further from the forest and 
the exploration of land is no longer as intense. Some studies have demonstrated that environmental alterations may affect mosquito populations in term of abundance and species composition [40-42].

Few field studies focus on the structure of anophelines population in areas with different degrees of human activity in rural settlements in the Amazon $[17,43]$. However, it is a fact that $N y$. darlingi is the main vector of malaria in both settlements, regardless of the length of time the land has been in use. The main vector in different areas of Rondonia, as well as in most of the Brazilian Amazon is $N y$. darlingi $[26,40,44]$. This species is found in great abundance in the region and it is recognized as a highly anthropophilic vector [ 15 , $18,19,45,46]$. Biting activity of $N y$. darlingi, in general is bimodal, occurring at the beginning of dusk and at dawn [47-49]. However, patterns of biting activity can be influenced by location, vector density, seasonality, presence of hosts, types of housing and the distance between dwellings and the forest [21, 26, 40, 50, 51]. Biting activity in our areas of study was constant during the whole night, though more activity was registered at dusk. Similar results were reported in other $\mathrm{Ny}$. darlingi studies in other areas of Amazon Basin such as endemic areas in the state of Rondonia, Brazil [52] and Iquitos, Peru [53]. The habits of settlers, housing conditions and distance from forest fringe observed at both locations may explain this pattern of anopheline activity. The settlement which showed the highest concentration of $\mathrm{Ny}$. darlingi at the first part of the night was the more recently settled area, where settlers were more exposed to the vector due poor local housing conditions and the type of human activity found there.

Our data regarding HBR also confirm the effect of "frontier" malaria concept in areas which are undergoing transformation. The human-biting rate (HBR) was higher in the AF ( 5.70 bites/person/hour) than in the PAFJ ( 0.71 bites/person/hour). Therefore, an individual who lives or visits the AF during the period of activity of $N y$. darlingi is almost five times more exposed to mosquito bites than an individual in the PAFJ. However, for the number of infective bites represented by the EIR, our data showed that the settlers and visitors of the PAFJ are more exposed to infective bites ( 0.05 infective bites/person/hour) than settlers and visitors of the PAFJ (0.02 infection bites/person/hour). The low EIR recorded at the AF was possibly determined by the low SR $(0.36 \%)$ and high vector density of the location. The PAFJ showed the highest SR $(7.35 \%)$ of the two locations, although it did present a lower HBR. However, it is known that $\mathrm{Ny}$. darlingican maintain transmission even at very low density [54-56].

The API at the PAFJ was higher (> 50) in 2018 and 2019, although, since 2012, the API in PAFJ has decreased with 295.08 in 2017. At the last stage of "frontier" malaria concept, malaria declines after 10 years of colonization and development in the settlement, and reaches low and stable levels of transmission because of the reduction in environmental changes. However, the infection risk in these older settlements could also be determined by behavioral factors of the population [9]. The risk of contracting malaria in PAFJ was greater in the first part of night, since the majority of infected mosquitoes were captured before midnight and only one was captured after midnight. In addition, individuals are unprotected outside due the existence of bars and the frequency of truckers that spend the night at the location. Another important point is that the lack of local healthcare facilities and the precarious access roads, which make the rapid diagnosis and effective treatment of malaria difficult, mainly during rainy season. 
The unexpectedly low EIR at the AF probably do not truly represent the risk of malaria infection at this recent settlement. The API in this settlement has also been higher (> 50) in 2018 and 2019, and was higher than PAFJ, which is as expected for a recent settlement; in addition, the density of $\mathrm{Ny}$. darlingi and HBR reported here was higher than the older settlement.

A parameter that was not assessed here was the parity of female mosquitoes collected and this is a factor that could have interfered with the EIR. If the majority of female mosquitoes from AF were nulliparous females, these females were not infected because they were getting their first blood meal [40], which may explain the low EIR in recent settlement. Regarding the risk of contracting malaria at this location, this is most likely in the middle of the night, when the majority of infected mosquitoes were captured and when people are inside their dwellings, though the conditions of the dwellings do not offer much protection since they are built with holes between the wooden slats and often have unscreened windows.

In general, although our study has some limitations, these entomological data may be used for planning and implementing vector control measures that are aligned with the malaria transmission dynamics of each of the settlements. Considering that the few strategies of control were implemented without any information about the local mosquito vector, the information presented here could aid in implementing a more effective control strategy.

\section{Conclusions}

The results obtained here represent an important contribution to entomological knowledge in settlements in the municipality of Candeias do Jamari. Our research confirmed that $\mathrm{Ny}$. darlingi, the main vector of malaria in the state of Rondonia, is the predominant anopheline species in both studied locations. The number of species recorded in the study was low, despite the two locations having different levels of human settlement. This is probably due the number of sample collections, the sites of sample collections (outdoors) or due to the of anthropophilic feature of $\mathrm{Ny}$. darlingi and its adaptation to its surroundings.

The risk of contracting malaria was recorded both in the area of recent occupation and in the old settlement. Despite the AF location having registered a low SR and EIR, this area of recent occupation presented the highest HBR, and the conditions of the dwellings and human behavior are believed to contribute to the greater contact between man and the vector. In addition, the data for EIR and malaria cases from the PAFJ confirm that $\mathrm{Ny}$. darlingi, even at low density, could maintain malaria transmission.

Specific strategies based on our entomological investigation and human behavior may be developed and tested in this setting.

\section{Abbreviations}

AF: Acampamento Fortaleza; CEPEM- RO: Rondônia Tropical Medicine Research Center; CSP: Circumsporozoitic Protein; DNA: Deoxyribonucleic Acid; EDTA: Ethylenediamine tetraacetic acid; INCRA: National Institute for Colonization and Agrarian Reform; API: Annual Parasitic Index; MS: Ministry of Health; WHO; World Malaria Report; PAFJ: Projeto de Assentamento Florestal Jequitibá; PCR: Polymerase chain 
reaction; SDS: Dodecyl Sodium Sulfate; SIVEP: Computerized Epidemiological Surveillance System; SR Sporozoite Rate; EIR: Entomological Inoculation Rate; HBR - Human Biting Rate; PHAT: Protected Human Attraction Technique; SISBIO: Biodiversity Authorization and Information System; SisGen: National System of Genetic Heritage Management and Associated Knowledge.

\section{Declarations}

\section{Acknowledgements}

We would like to thank the families who reside in the Acampamento Fortaleza and Projeto de Assentamento Florestal Jequitibá, in addition to the Endemic team from the Municipality of Candeias do Jamari for their support in this study.

\section{Ethics approval and consent to participate}

Ethical approval for the study was obtained from the regional committee (Research Center of Tropical Medicine - CEPEM, No 2976746). Mosquito collections were conducted by the authors of this manuscript after training in according with the instructions of Brazilian Ministry of Health [57]. In addition, the study has a license from the Brazilian government: SISBIO No 65725-1 and SisGen No. A948A47.

\section{Consent for publication}

Not applicable.

\section{Availability of data and materials}

Data supporting the conclusions of this article are included within the article.

\section{Competing interests}

Not applicable.

\section{Funding}

This study was financed in part by the Coordenação de Aperfeiçoamento de Pessoal de Nível Superior Brasil (CAPES) - Financial code 001.

\section{Authors' contributions}


AOA conducted the sample collection, identified the insects, prepared the anopheles for molecular analysis and wrote the manuscript; NACS, RBC, ISA, ASB and FNM participated in the collection of the material; MMSR: helped to prepare the study; DBP and JFM prepared the study and helped to write the manuscript; MSA did the formal analysis, project administration, supervision and writing the manuscript. All authors read and approved the final manuscript.

\section{Author details}

${ }^{1}$ Laboratório de Entomologia - Plataforma de Produção e Infecção de Vetores da Malária (PIVEM), Fundação Oswaldo Cruz - Fiocruz Rondônia, 76812-245, Porto Velho, RO, Brazil.

${ }^{2}$ Programa de Pós-Graduação em Biologia Experimental, Fundação Universidade Federal de Rondônia, 76801-059, Porto Velho, RO, Brazil.

${ }^{3}$ Centro Universitário Aparício Carvalho (FIMCA), 76812-000, Porto Velho, RO, Brazil

${ }^{4}$ Ambulatório de malária, Centro de Pesquisa em Medicina Tropical, 76812-329, Porto Velho, RO, Brasil

${ }^{5}$ Instituto Nacional de Ciência e Tecnologia de Epidemiologia da Amazônia Ocidental - INCT-EpiAm0, 76812245, Porto Velho, RO, Brazil.

\section{References}

1. Recht J, Siqueira AM, Monteiro, WM, Herrera SM, Herrera S, Lacerda MV. Malaria in Brazil, Colombia, Peru and Venezuela: current challenges in malaria control and elimination. Malar J. 2017;16:273; doi: 10.1186/s12936-017-1925-6.

2. World Health Organization. World malaria report 2019. Geneva: World Health Organization; 2019. https://www.who.int/publications/i/item/9789241565721. Accessed mar 2020.

3. Brasil. Ministério da Saúde/Secretaria de Vigilância em Saúde. 2016. Plano de Eliminação da malária no Brasil. Ministério da Saúde: Brasília, Brazil, p. 41, 2016.

https://portalarquivos2.saude.gov.br/images/pdf/2017/janeiro/04/Plano-eliminacao-malaria-pub.pdf. Accessed Jan 2020.

4. Siqueira A, Marchesini P, Torres RM, Rodovalho S, Chaves T. Malária na Atenção Básica. Belo Horizonte: Nescon/UFMG, 2018. https://www.nescon.medicina.ufmg.br/biblioteca Accessed dez 2019.

5. Braz RM, Duarte EC, Tauil PL. Caracterização das epidemias de malária nos municípios da Amazônia Brasileira em 2010. Cadernos de Saúde Pública, 2013. 29: 935-944. https://www.scielosp.org/article/csp/2013.v29n5/935-944/. Accessed dez 2019:

6. Sivep-Malaria_Dados para o cidadão, 2020. https://public.tableau.com/profile/mal.ria.brasil\#!/vizhome/Dadosparacidado_201925_03_2020/Ttulo Accessed oct 2020. 
7. Ferreira, AMM, Salati E. Forças de transformação do ecossistema amazônico. Estudos Avançados.2005;19:25-43; doi: 10.1590/S0103-40142005000200003

8. Incra - Instituto Brasileiro de Colonização e Reforma Agrária. Superintendência Regional de Rondônia. Divisão de Suporte Operacional. Informações Gerais - Projetos de Assentamento e Colonização, 2020. http://painel.incra.gov.br/sistemas/index.php. Accessed oct 2020:

9. Castro MC, Monte-Mó RL, Sawyer DO, Singer BH: Malaria risk on the Amazon frontier. PNAS 2006, 103:2452-57. doi. 10.1073/pnas.0510576103

10. Ferreira UM, Castro MC. Challenges for malaria elimination in Brazil. Malar J. 2016; 15:284; doi 10.1186/s12936-016-1335-1

11. Tadei WP, Dutary TB, Santos JM, Scarpassa VM, Rodrigues IB, Rafael, MS. Ecologic observations on anopheline vectors of malaria in the Brazilian Amazon. Am J Trop Med Hyg. 1998; 59:325-35.

12. Moutinho PR, Gil LHS, Cruz RB, Ribolla PEM. Population dynamics, structure and behavior of Anopheles darlingi in a rural settlement in the Amazon rain forest of Acre, Brazil. Malar J. 2011; 10:1-13. doi: 10.1186/1475-2875-10-174

13. Foster PG, De Oliveira TMP, Bergo ES, Conn JE, Sant'ana DC, Nagaki SS, Sallum MAM. Phylogeny of Anophelinae using mitochondrial protein coding genes. R. Soc. Open Sci. 2017;4; 170758; doi $10.1098 /$ rsos. 170758

14. Klein TA, Lima JBP, Tada MS, Miller R. Comparative susceptibility of anopheline mosquitoes in Rondônia, Brasil to infection by Plasmodium vivax. Am J Trop Med Hyg. 1991; 45; 463-470.

15. Gil LHS, Alves FP, Zieler H, Salcedo JMV, Duarlacher RR, et al. Seasonal malaria transmission and variation of anopheline density in two distinct endemic areas in Brazilian Amazon. J Med Entomol. 2003; 40: 636-41; doi: 10.1603/0022-2585-40.5.636

16. Kiszewski A, Mellinger A, Spielman A, Malaney P, Sachs SE, Sachs J. A global index representing the stability of malaria transmission. Am J Trop Med Hyg. 200; 70: 486-498; doi: 10.4269/ajtmh.2004.70.486

17. Vittor AY, Gilman RH, Tielsch J, Glass G, Shields T, Sánchez LW, Pinedo-Cancino V, Patz JA. The effect of deforestation on the human-biting rate of Anopheles darlingi, the primary vector of falciparum malaria in the Peruvian Amazon. Am J Trop Med Hyg. 2006; 74: 3-11; doi: 10.4269/ajtmh.2006.74.3

18. Gil LHS, Tada MS, Katsuragawa TH, Ribolla PEM, Pereira Da Silva LH. Urban and suburban malaria in Rondônia (Brazilian Western Amazon) II. Perennial transmissions with high anopheline densities are associated with human environmental changes. Mem Inst Oswaldo Cruz. 2007;102: 271-276; doi:10.1590/S0074-02762007005000013

19. Gil LHS, Rodrigues MS, Lima AA, Katsuragawa TH. Seasonal distribution of malaria vectors (Diptera: Culicidae) in rural localities of Porto Velho, Rondônia, Brazilian Amazon. Revi. I. Med. Trop. São Paulo. 2015; 57:263-267; doi:10.1590/S0036-46652015000300014

20. Sallum MAM, Conn JE, Bergo ES, Laporta GZ, Chaves LS, Bickersmith SA, Struchiner CJ. Vector competence, vectorial capacity of Nyssorhynchus darlingi and the basic reproduction number of Plasmodium vivax in agricultural settlements in the Amazonian Region of Brazil. Malar J. 2019; 18:117; doi: 10.1186/s12936-019-2753-7 
21. Forattini OP. Culicidologia médica - Identificação, biologia e epidemiologia, Vol. 2, ED. USP, São Paulo, p.864, 2002.

22. Valle D, Ben Toh K, Laporta GZ, Zhao Q. Ordinal regression models for zero-inflated and/or overdispersed count data. Sci Rep. 2019;9:3046.; doi: 10.1038/s41598-019-39377-x

23. Laporta G, Burattini M, Levy D, Fukuya L, de Oliveira T, Maselli L, et al. Plasmodium falciparum in the southeastern Atlantic forest: a challenge to the bromeliad-malaria paradigm? Malar J. 2015;14:181; doi:10.1186/s12936-015-0680-9

24. Conn JE, Wilkerson RC, Segura MN, de Souza RT, Schlichting CD, Wirtz RA, Povoa MM: Emergence of a new neotropical malaria vector facilitated by human migration and changes in land use. Am J Trop Med Hyg. 2002, 66: 18-22; doi: 10.4269/ajtmh.2002.66.18

25. Bourke BP, Conn JE, de Oliveira TMP, Chaves LSM, Bergo ES, Laporta GZ, et al. Exploring malaria vector diversity on the Amazon Frontier. Malar J. 2018; 17:342; doi: 10.1186/s12936-018-2483-2

26. Hiwat H, Bretas G. Ecology of Anopheles darlingi root with respect to vector importance: a review. Par Vect. 2011;4:177; doi: 10.1186/1756-3305-4-177

27. Brasil, 2019. A coleção institucional do Ministério da Saúde pode ser acessada, na íntegra, na Biblioteca Virtual em Saúde do Ministério da Saúde: Tiragem: $1^{\text {a }}$ edição - 2019 - versão eletrônica PRELIMINAR.

28. Santos RL, Padilha A, Costa MD, Costa EM, Dantas-Filho HC, Povoa MM: Malaria vectors in two indigenous reserves of the Brazilian Amazon. Rev Saúde Pública. 2009; 43: 859-68; doi: 10.1590/S003489102009000500016

29. BRASIL. Ministério da Saúde. Secretaria de Vigilância em Saúde. Coordenação-Geral de Desenvolvimento da Epidemiologia em Serviços. Guia de Vigilância em Saúde: volume 3 / Ministério da Saúde, Secretaria de Vigilância em Saúde, Coordenação-Geral de Desenvolvimento da Epidemiologia em Serviços. - 1. ed. atual. - Brasília: Ministério da Saúde, 2017.https://www.hc.ufu.br/sites/default/files/tmp//volume_3_guia_de_vigilancia_em_saude_2017.pdf. Accessed dez 2019:

30. Incra. Instituto Nacional de Colonização e Reforma Agrária. Portaria/INCRA n 1.141/2003: Cria a modalidade de Projeto de Assentamento Florestal-PAF. Diário Oficial da União, 2004.

31. Datasus. Sivep-Malária. Sistema de Informação de Vigilância. Epidemiológica Portal Ministério da Saúde. 2019. http://200.214.130.44/sivep_malaria/relatorio/rel_resumo_municipio_infeccao.asp? cd_uf_relatorio=21\&cd_municipio_relatorio=3850\&tx_uf_relato... Accessed Jan 2019.

32. Consoli RGB, Lourenço-De-Oliveira R. Principais Mosquitos de Importância Sanitária. Rio de Janeiro, Editora Fiocruz. 225Pp, 1994. ISBN: 85-85676-03-5. $1^{\text {a }}$ reimpressão: 1998 (1ª edição: 1994).

33. 33. Foley DH, Harrison G, Murphy JR, Dowler M, Rueda LM, Wilkerson RC (2012) Mosquito bisection as a variable in estimates of PCR-derived malaria sporozoites rates. Malar J. 2012; 11:145. doi:10.1186/1475-2875-11-145

34. Win TT, Lin K, Mizuno S, Zhou M, Liu Q, Ferreira MU, Tantular IS, Kojima S, Ishii A, Kawamoto F. Wide distribution of Plasmodium ovale in Myanmar. Trop Med Int Health. 2002; 7:231-239. doi: 
10.1046/j.1365-3156.2002.00857. X.

35. Chaves LSM, Conn JE, López RVM, Sallum MAM. Abundance of impacted forest patches less than 5 $\mathrm{km} 2$ is a key driver of the incidence of malaria in Amazonian Brazil. Sci Rep. 2018; 8:7077; doi: 10.1038/s41598-018-25344-5

36. Vittor AY, Pan W, Gilman RH, Tielsch J, Glass G, Shields T, Sanchez-Lozano W, Pinedo VV, Salas-Cobos E, Flores S, Patz JA: Linking deforestation to malaria in the Amazon: characterization of the breeding habitat of the principal malaria vector, Anopheles darlingi. Am J Trop Med Hyg. 2009;81: 5-12. PMID: 19556558; PMCID: PMC3757555.

37. Reis IC, Codeço CT, Câmara DCP, Carvajal JJ, Pereira GR, Keppeler EC, et al. Diversity of Anopheles spp. (Diptera: Culicidae) in an Amazonian urban area. Neotrop Entomol. 2018;47:412-417; doi:10.1007/s13744-018-0595-6

38. 38. Martins-Campos KM, Pinheiro WD, Vítor-Silva S, Siqueira AM, Melo GC, Rodrigues ÍC, et al. Integrated vector management targeting Anopheles darlingi populations decreases malaria incidence in an unstable transmission area, in the rural Brazilian Amazon. Malar J. 2012;11:351; doi: 1186/1475-287511-351

39. Barbosa LMC, Souto RNP, Dos Anjos Ferreira RM, Scarpassa VM. Behavioral patterns, parity rate and natural infection analysis in anopheline species involved in the transmission of malaria in the northeastern Brazilian Amazon region. Acta Trop. 2016; 164:216-25;

doi:10.1016/j.actatropica.2016.09.018

40. Tadei WP, Dutary-Thatcher B: Malaria vectors in the Brazilian Amazon: Anopheles of the subgenus Nyssorhynchus. Rev Inst Med Trop São Paulo. 2000; 42: 87-94; doi: 10.1590/S003646652000000200005.

41. Roux E, Gaborit P, Romana CA, Girod R, Dessay N, Dusfour I. Objective sampling design in a highly heterogeneous landscape-characterizing environmental determinants of malaria vector distribution in French Guiana, in the Amazonian region. BMC ecology. 2013; 13:45; doi:10.1186/1472-6785- 13-45

42. Rubio-Palis Y, Bevilacqua M, Medina DA, Moreno JE, Cardenas L, Sanchez V et al. Malaria entomological risk factors in relation to land cover in the Lower Caura River Basin, Venezuela. Mem Inst Oswaldo Cruz. 2013; 108:220-228; doi:10.1590/0074-0276108022013015.

43. Gomes ECS, Albuquerque CMR, Souza JRB, Arruda ME, Confalonieri UEC. Structure of Anopheles (Diptera: Culicidae) population in areas with different degrees of human settlement: Cantá-RoraimaBrasil. Acta Amaz.2008; 38:321-329; doi: 10.1590/S0044-59672008000200016

44. Deane LM, Ribeiro CD, Lourenço de Oliveira R, Oliveira Ferreira J, Guimarães AE. Study on the natural history of malaria in areas of the Rondônia State, Brazil, and problems related to its control. Rev Inst Med Trop São Paulo. 1988; 30:153-156; doi: 10.1590/S0036-46651988000300005

45. Katsuragawa T, Gil L, Tada M, de Almeida e Silva A, Costa J, Araújo MS, Escobar A, da Silva L: The dynamics of transmission and spatial distribution of malaria in riverside areas of Porto Velho, Rondônia, in the Amazon region of Brazil. PLoS One. 2010; 5: e9245; doi:

10.1371/journal.pone.0009245

Page 15/18 
46. Morais SA, Urbinatti PR, Sallum MAM, Kuniy AA, Moresco GG, Fernandes A, et al. Brazilian mosquito (Diptera: Culicidae) fauna: I. Anopheles species from Porto Velho, Rondônia state, western Amazon, Brazil. Rev Inst Med Trop Sao Paulo. 2012;54:331-5; doi: 10.1590/S0036-46652012000600008.

47. Charlwood JD: Biological variation in Anopheles darlingi Root. Mem Inst Oswaldo Cruz. 1996, 91: $391-$ 398; doi: 10.1590/S0074-02761996000400001

48. Santos RC, Sucupira IMC, Lacerda RNL, Fayal AS, Póvoa MM. Inquérito entomológico e infectividade durante epidemia de malária no município de Anajás, Estado do Pará. Rev Soc Bras Med Tropical. 2005; 38:2002-2204; doi:10.1590/S0037-86822005000200018

49. Galardo AKR. A importância dos Anopheles darlingi Root, 1926 e Anopheles marajoara Galvão e Damasceno, 1942 na transmissão de malária no município de Macapá/Ap-Brasil, Tese. Instituto de Ciências Biológicas: Universidade Federal do Pará; 2010.

50. 50. Charlwood JD, Hayes J: Variações geográficas no ciclo de picada do Anopheles darlingi Root no Brasil. Acta Amaz. 1978; 8: 605-611; doi:1590/1809-43921978084601

51. Quintero LO, Dutary- Thatcher B, Tadei WP. Biologia de anofelinos amazônicos. XXI. Ocorrência de espécies de Anopheles e outros Culicídeos na área de influência da Hidrelétrica de Balbina - cinco anos após o enchimento do reservatório. Acta Amaz, 1996;26:281-95; doi: 10.1590/1809-43921996264296

52. Gama RA, Santos RL, Santos FD, Silva IM, Resende MC, Eiras ÁE. Periodicity of capture of the Anopheles darlingi Root (Diptera: Culicidae) in Porto Velho, Rondônia, Brazil. Neotrop. entomol.2009. 38: 677-682; doi: 10.1590/S1519-566X2009000500019

53. Turell MJ, Sardelis MR, Jones JW, Watts DM, Fernandez R, Carbajal F, Pecor JE, Klein TA: Seasonal distribution, biology, and human attraction patterns of mosquitoes (Diptera: Culicidae) in a rural village and adjacent forested site near Iquitos, Peru. J Med Entomol. 2008; 45: 1165-1172; doi: 10.1603/00222585-41.3.349

54. Rubio-Palis Y, Zimmerman RH: Ecoregional classification of malaria vectors in the neotropics. J Med Entomol. 1997; 34: 499-510; doi: 10.1093/jmedent/34.5.499

55. Lounibos LP, Conn JE: Malaria vector heterogeneity in South America. Am Entomol. 2000, 46: 238-249; doi: 10.1093/ae/46.4.238

56. Povoa MM, de Souza RT, Lacerda RN, Rosa ES, Galiza D, de Souza JR, Wirtz RA, Schlichting CD, Conn JE: The importance of Anopheles albitarsis e and An. darlingi in human malaria transmission in Boa Vista, state of Roraima, Brazil. Mem Inst Oswaldo Cruz. 2006, 101: 163-168; doi: 10.1590/S007402762006000200008.

57. BRASIL. Ministério da Saúde. Secretaria de Vigilância em Saúde. Departamento de Imunização e Doenças Transmissíveis. Guia para o Planejamento das Ações de Captura de Anofelinos pela Técnica de Atração por Humano Protegido (TAHP) e Acompanhamento dos Riscos à Saúde do Profissional Capturador, Ministério da Saúde, Secretaria de Vigilância em Saúde, Departamento de Imunização e Doenças Transmissíveis. - Brasília: Ministério da Saúde, 2019.

http://bvsms.saude.gov.br/bvs/publicacoes/guia_captura_anofelinos_tahp.pdf. Accessed Jan 2020.

\section{Figures}




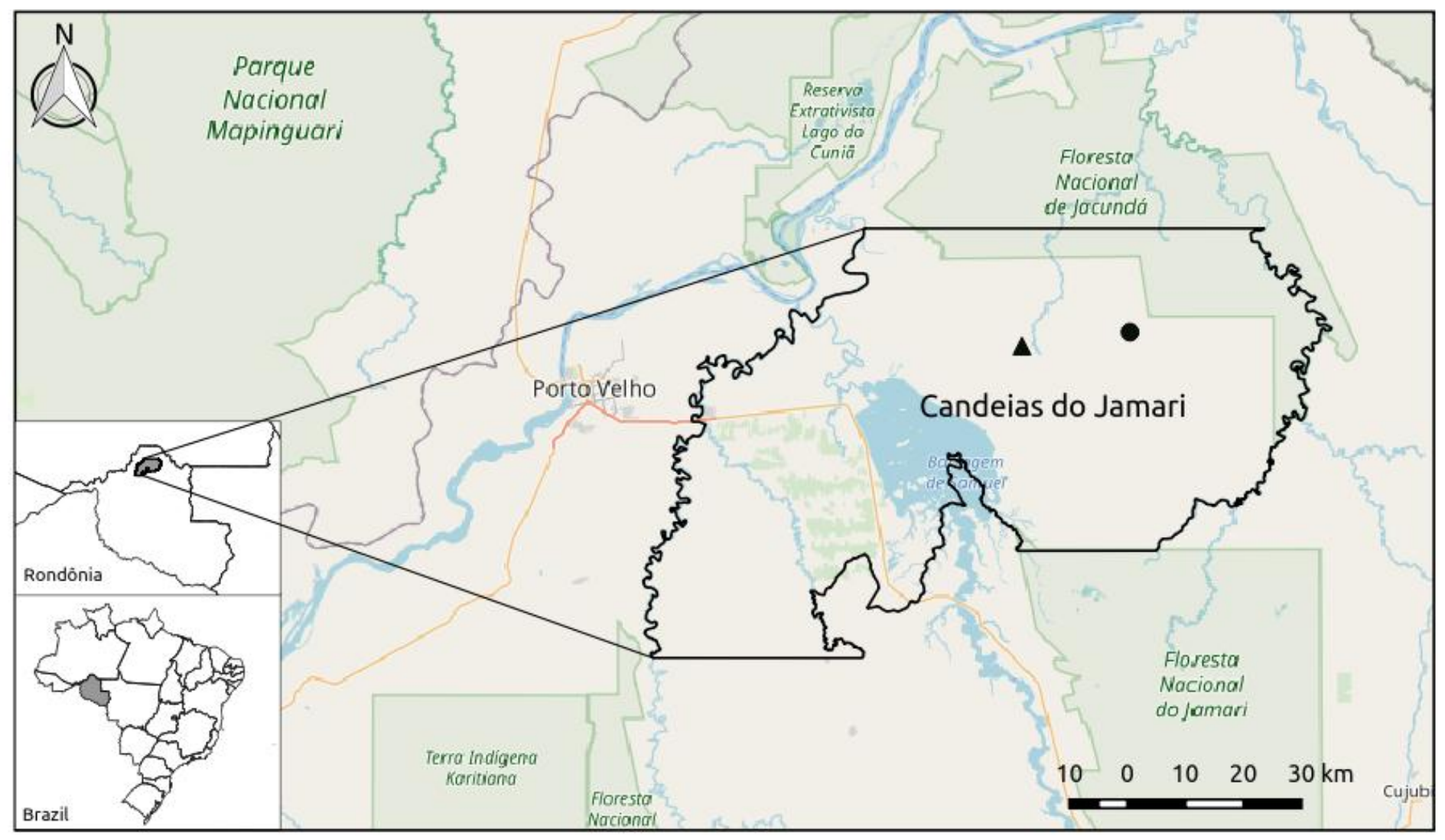

\section{Figure 1}

Location of the municipality of Candeias do Jamari in northwest of the Rondônia state, Brazil. Sample collection locations: Projeto de Assentamento Florestal Jequitibá (PAFJ) and Acampamento Fortaleza (AF) are identified as triangle and circle, respectively.

\section{STUDY LOCATIONS}

PAFJ

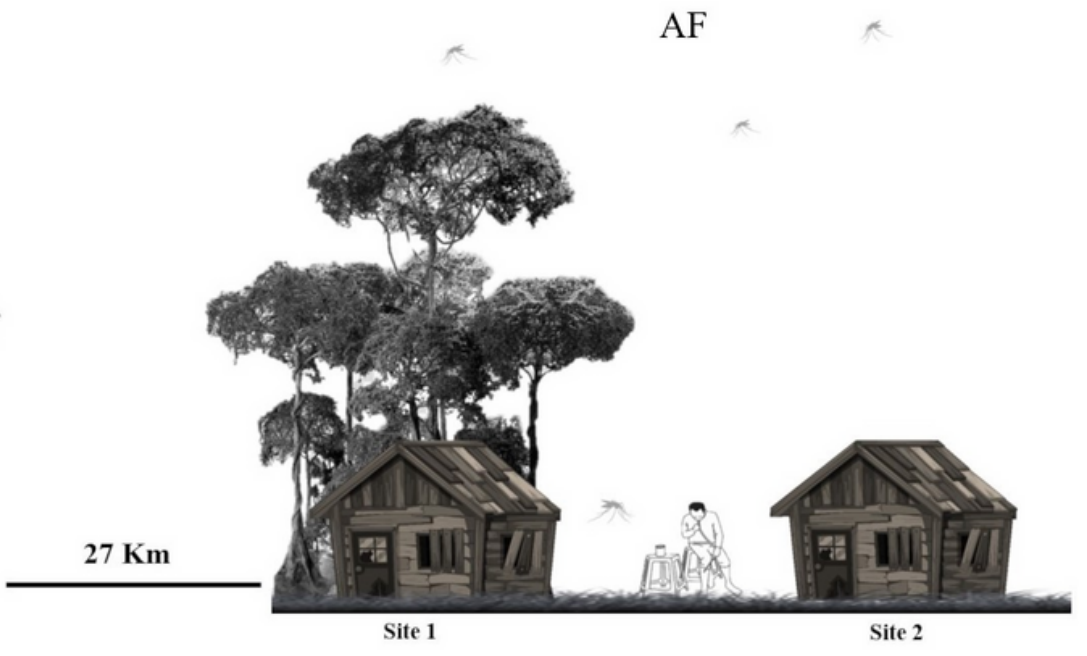

Figure 2 
Schematic representation of outdoor capture sites in typical rural settlements showing the difference between the dwellings in Projeto de Assentamento Florestal Jequitibá (PAFJ) and Acampamento Fortaleza (AF).

\section{Supplementary Files}

This is a list of supplementary files associated with this preprint. Click to download.

- Graphicalabstract3.tiff 